\title{
The antigen presenting cells instruct plasma cell differentiation
}

\author{
Wei $\mathrm{Xu}^{1 *}$ and Jacques Banchereau ${ }^{2}$ \\ 1 Pharma Research and Early Development, F. Hoffmann-La Roche Ltd., Roche Glycart AG, Schlieren, Switzerland \\ 2 The Jackson Laboratory, Institute for Genomic Medicine, Farmington, CT, USA
}

\author{
Edited by: \\ Catherine Pellat-Deceunynck, Centre \\ National de la Recherche Scientifique, \\ France \\ Reviewed by: \\ Laurence Morel, University of Florida, \\ USA \\ Paulo Vieira, Institut Pasteur de Paris, \\ France \\ Gaetan Jego, University of Burgundy, \\ France \\ *Correspondence: \\ Wei Xu, Human Immunology Unit, \\ Pharma Research and Early \\ Development, Hoffmann-La Roche \\ Ltd., Roche Glycart AG, Wagistrasse \\ 18, Schlieren 8952, Switzerland \\ e-mail:wei.xu.wx6@roche.com
}

The professional antigen presenting cells (APCs), including many subsets of dendritic cells and macrophages, not only mediate prompt but non-specific response against microbes, but also bridge the antigen-specific adaptive immune response through antigen presentation. In the latter, typically activated B cells acquire cognate signals from T helper cells in the germinal center of lymphoid follicles to differentiate into plasma cells (PCs), which generate protective antibodies. Recent advances have revealed that many APC subsets provide not only "signal 1" (the antigen), but also "signal 2" to directly instruct the differentiation process of PCs in a T-cell-independent manner. Herein, the different signals provided by these APC subsets to direct B cell proliferation, survival, class switching, and terminal differentiation are discussed. We furthermore propose that the next generation of vaccines for boosting antibody response could be designed by targeting APCs.

Keywords: plasma cells, antigen presenting cells, macrophages, dendritic cells, B cells

\section{INTRODUCTION}

$B$ cell activation is initiated following engagement of the B cell receptor (BCR) by a specific antigen in either a T-cell-dependent (TD) or T-cell-independent (TI) manner (1). Most long-lived plasma cells (PCs) in the bone marrow are derived from TD responses involving germinal center reactions followed by niches favoring long-term survival. As it usually takes several days for the cognate $\mathrm{T}$ cells to help, a prompt TI response provides the first wave of humoral protection by generating short-lived PCs in the extrafollicular foci of the peripheral lymphoid organs such as lymph nodes, spleen, Peyer's patches, and tonsils (2). Indeed, some TI challenges could also induce long-lived antibody responses (3-5).

Professional antigen presenting cells (APCs), including dendritic cells (DCs) and macrophages, present antigens to $\mathrm{T}$ cells to initiate adaptive immunity by sequentially delivering signal 1 (antigen), signal 2 (co-stimulation), and signal 3 (polarizing signals mediated by soluble or membrane-bound factors) (6). They can, by similar means, initiate and guide B cell differentiation toward PCs in a TI manner. Precisely, DCs and macrophages efficiently take up large size antigens (such as particulates, immune complexes, and virus that travel through the subcapsular sinus), and present them to naïve $B$ cells in the periphery lymphoid organs (2). Recent advances have revealed that APCs deliver not only signal 1, but also late signals to instruct terminal differentiation of PCs in both a TI and TD manner. In a TD manner, CD40-CD40L interaction between $B$ cells and cognate $T$ cells is instrumental in driving germinal center formation for affinity maturation. Whereas in a TI manner, APC-derived factors and the ligand-receptor signals between APC and B cells combines to deliver signals for PC differentiation (Figure 1). This review discusses the signals provided by these APC subsets and shapes a rationale of designing therapeutic vaccines for humoral immunity by targeting APCs.

\section{SUBSETS INSTRUCT B CELL DIFFERENTIATION}

Back in the 1990s, following the early milestone discovery of DCs in mouse (7) and human (8), DCs have been recognized for their capacity of priming naïve B cells in human in vitro settings (911). In the presence of $C D 40$ signaling, naïve $B$ cells undergo class switching toward IgA1 and IgA2 isotype by DCs, and class switching (11). These early works using human monocyte-derived DCs provided the first evidence that in addition to their capacity to activate naive $T$ cells in the extrafollicular areas of secondary lymphoid organs, DCs may directly modulate B cell growth and differentiation. Similarly, mouse splenic DCs were able to interact with naïve $\mathrm{B}$ cells and induce TI class switching in vitro and in vivo (12).

Dendritic cells directly induce TI Ab class switching through the upregulation of $\mathrm{B}$ lymphocyte stimulator protein (BLyS, also known as BAFF), and a proliferation-inducing ligand (APRIL) (13). BAFF binds to three different receptors, namely transmembrane activator and calcium modulator and cyclophylin ligand interactor (TACI), B cell maturation antigen (BCMA), and BAFF receptor (BAFF-R) (14-18). On the other hand, APRIL binds to BCMA with high affinity and to TACI with low affinity, but not to BAFF-R $(19,20)$. Through engagement with its receptors, BAFF activates a CD40-like pathway that enhances $B$ cell survival via upregulation of NF- $\kappa \mathrm{B}$ and Bcl-2 (21). APRIIL appears to induce AID expression in $\mathrm{B}$ cells through NF- $\mathrm{kB}$-mediated HoxC4 induction (22). The importance of BAFF and APRIL has been documented in animal models where mice deficient for BAFF or APRIL showed a defect in IgA production $(23,24)$. Interestingly, B cells exposed to BAFF and APRIL do not secrete IgG and IgA 


\section{T-dependent}

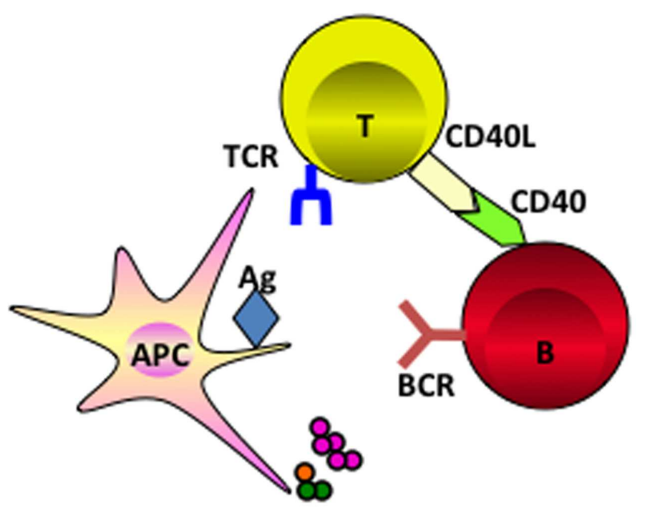

T-independent

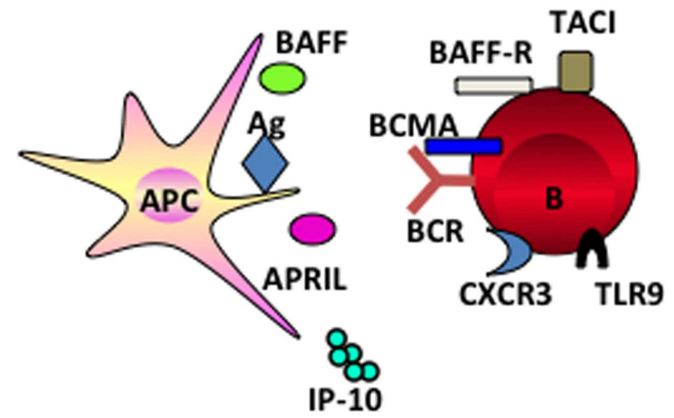

FIGURE 1 | APC subsets induce TI and TD B cell activation. APC subsets including DCs and macrophages, have the capacity to retain and recycle native antigens on their surface and engage with $B$ cell receptor for the signal 1 delivery. Ag-experienced $B$ cells receive cognate $T$ cell signals to form germinal center for the generation of long-lived PCs in a TD manner. Alternatively, APC-derived soluble factors provide late signals to B cells that have the respect receptors during the activation, proliferation, and differentiation, in a TI manner.

unless stimulated through extensive BCR cross-linking. Thus, in a process of DC-mediated $\mathrm{B}$ cell differentiation, DCs initially provide $\mathrm{TI}$ antigens to engage $\mathrm{BCR}$ on $\mathrm{B}$ cells for activation. Thereafter, co-signals from other DC-derived factors like BAFF or APRIL or cytokines such as IL-15 cooperatively instruct the terminal differentiation of activated B cells into PCs (13).

Heterogeneous populations of DCs have been discovered in both human and mouse (25). In humans, three subsets have been identified in blood, namely $\mathrm{CD} 03^{+}$plasmacytoid DCs (pDCs), $\mathrm{CD}_{1} \mathrm{c}^{-} \mathrm{CD} 141^{+}$, and $\mathrm{CD} 1 \mathrm{c}^{+} \mathrm{CD} 141^{-}$circulating DCs (26-28). In the skin, cutaneous DCs express a distinct set of receptors as compared to blood DCs, i.e., langerin ${ }^{+}$langerhans cells and $\mathrm{CD} 14^{+}$ interstitial dermal DCs $(29,30)$. Among all subsets, interstitial dermal DCs that represent the in vivo counterpart of in vitro monocyte-derived DCs, appear to be the ones that preferentially prime $\mathrm{B}$ cells for humoral response while poorly triggering $\mathrm{CD} 8^{+}$ $\mathrm{T}$ cell immunity (31), owing to their capacity to polarize follicular Thelp cells (Tfh) via DC-derived molecular such as IL-6 (32-34).

Plasmacytoid DCs, the professional type-1 interferon (IFN)producing cells, promote the differentiation of $\mathrm{CD} 40$-stimulated $\mathrm{B}$ cells into non-antibody-secreting plasmablasts via IFN- $\alpha \beta$. They sequentially differentiate into antibody-secreting PCs upon additional IL-6 secreted by pDCs (35). Both B cells and pDCs express TLR9. IFN- $\alpha$ production by CpG ligation of the TLR9 on pDCs also generate IgM-producing PCs from both naïve and memory $\mathrm{B}$ cells in a TI manner, under the help of other pDC-derived factors such as IL-6, TNF- $\alpha$, and IL-10 (36). TLR9 ligation of pDCs enhances their CD70 expression to trigger CD27 signaling for B cell survival and differentiation, particularly on memory cells (37). Type-1 IFN can also contribute to PC differentiation indirectly via the upregulation of BAFF and APRIL on myeloid DCs to promote B cell survival, proliferation, and class switching (38), or via promoting Tfh differentiation through myeloid DCs (39). In autoimmune disorders such as systemic lupus erythematosus (SLE), pDCs could be the driver favoring persistence of autoreactive PCs, giving the abnormal signature of type-1 IFN and autologous DNA and DNA-binding proteins (40-42). Indeed, activated pDCs trigger anti-snRNP B cells for enhanced proliferation and antibody production in the mouse (43).

How do B cells acquire antigens from DCs? DCs are found not only in the $\mathrm{T}$ cell areas of lymphoid organs where they are ready to prime $\mathrm{T}$ cells, but are also interacting with $\mathrm{B}$ cells in the follicular areas (44), the red pulp (45), and the marginal zones (46). DCs have a specialized capacity for the retention of antigens (44), enabling delivery of microbes from the intestinal lumen to secondary lymphoid structures $(47,48)$. Intravital two-photon imaging has revealed that upon lymph node entry, B cells physically survey local antigen-carrying DCs (49). DCs use different receptors to sample antigens that are directed to the degradative compartment for peptide and MHC loading. Interestingly, those antigens or immune complexes internalized by the inhibitory Fc $\gamma$ RIIB on DCs were stored in a recycling versical system, largely excluded from the LAMP- $1^{+}$degradative compartment (50). As a consequence, these antigens were trapped in a native form, and recycled to the cell surfaces for the activation of $B$ cells. This strategy for sorting and recycling native antigens through a nondegradative compartment is also used by follicular DCs to access B cells (51). Another inhibitory receptor, dendritic cell immunoreceptor (DCIR), holds the similar property as Fc $\gamma$ RIIB for native antigen recycling utilized by marginal zone DCs to initiate B cell activation in a TD manner (52). It has been reported that even in the degradative late endosome, antigens can be released unprocessed by DCs (53). Thus DCs are equipped with an array of machinery to efficiently retain native antigens to BCR engagement on naïve B cells in a TI or TD manner.

\section{MACROPHAGE SUBSETS INSTRUCT B CELL DIFFERENTIATION}

Due to the nature of lymphoid structure, it has been conceived for a long time that lymph-born antigens must pass through a zone of macrophages that are beneath the subcapsular sinus en route 
to reach the follicular B cells (54-56). Macrophages are known to retain antigens for up to $72 \mathrm{~h}$ after being exposed to them (57). The very first evidence that macrophages process large size antigens (immune complexes, particulates, and viruses) to present to follicular B cells were found by three impendent groups (58-61). The subcapsular sinus macrophages possibly use CD169 or MAC1 (macrophage receptor 1) to retain antigens on their surface, and consequently B cells acquire antigens from them cumulatively and became the main antigen carriers inside the follicle before polarizing to the B cell-T cell border $(58,59)$. These studies clearly defined the essential roles of macrophage subsets in the initiation of $B$ cell activation toward lymph-born antigens through dual actions: (1) as innate "flypaper" by preventing the systemic spread of pathogen; (2) as "gatekeepers" at the lymph-tissue interface that facilitate the recognition antigens by $\mathrm{B}$ cells and initiate humoral immune responses.

Macrophages residing in the marginal zone have the similar capacity to capture antigen in the spleen (62). Marginal zone macrophages (MZM) express a distinct set of receptors MARCO (macrophage receptor with a collagenous structure) and/or SIGNR1 (a mouse homolog of DC-SIGN), and are therefore different from metallophilic macrophages that express MOMA-1. The first study performed by Ravetch and his colleagues showed that $\mathrm{MARCO}^{+} \mathrm{MZM}$ migrate to the red pulp of the spleen and transfer the intact antigens to B cells (63). It seems that SIGNR1 is important for the MZM-mediated B cell response, as MZM that lack expression of SIGNR1 failed to capture the model antigen Ficoll (64), and mice deficient for SIGNR1 failed to mount a humoral response following infection with Streptococcus pneumoniae (65).

In humans, the evidence for an exclusive role of macrophages in the induction of humoral response remains scarce. We recently identified that resident tissue macrophages in human tonsils reside closely to the terminally differentiated CD $138^{+}$PCs. We went on to unravel that macrophage-derived IP-10 participates in PC development (proliferation, class switching, and terminal differentiation) in the context of an amplification loop where B cell-derived IL-6 induces macrophages to secrete IP-10, which further boosts the B cell autocrine secretion of IL- 6 leading to PC differentiation (Figure 2) (66). This is the first evidence that a chemokine plays direct role in cell differentiation. In addition, macrophages use VCAM-1 to tether B cells for the delivery of signals (66), supporting the earlier findings that VCAM-1 receptor-ligand interaction promotes membrane-bound antigen recognition and formation of an immune synapse (67).

Like DCs, macrophages promote TI class switching recombination by releasing the essential factors BAFF and APRIL (6870). Macrophage-derived BAFF and APRIL expression can be enhanced by $\mathrm{T}$ cell signals such as IFN- $\gamma$ and CD40L (68). B cell proliferation and antibody secretion following by BAFF and APRIL stimulation also requires co-stimulatory signals such as IL6 , IL-10, and TGF- $\beta(13,68,70)$. This also implies that there are redundant signaling pathways involved in PC differentiation. For example, in rodents, subcapsular macrophages activate extrafollicular B cells indirectly through presenting CD1d-restricted glycolipid antigens to iNKT cells. PCs homing to the bone marrow require survival niches for long-term residence, and macrophages

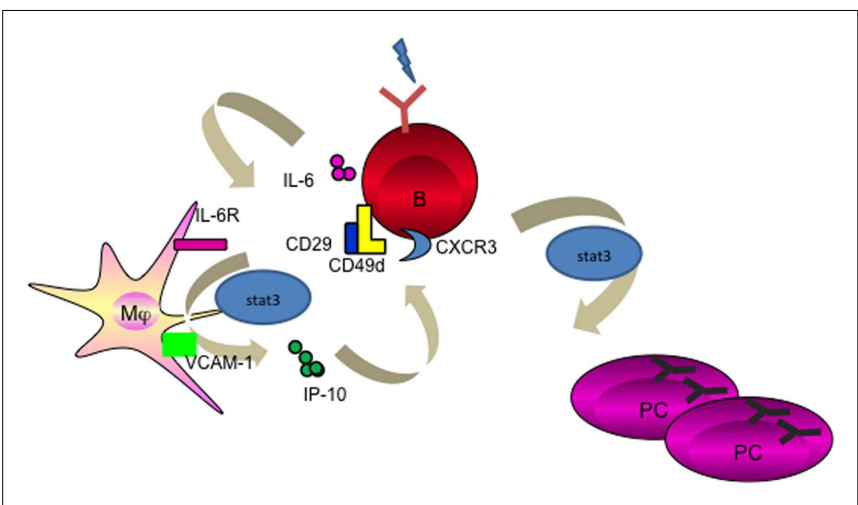

FIGURE 2 | Macrophage mediates PC differentiation. Activated B cells release IL-6 to activate macrophage through STAT3. Macrophage-derived IP-10 sequentially binds to CXCR3 on B cells to trigger amplification loop production of IL-6, leading to STAT3-dependent PC differentiation.

and their precursors provide such help through APRIL and IL-6 (71-73).

\section{TARGETING APCs FOR A BETTER VACCINE FOR HUMORAL IMMUNITY}

Accumulating evidence suggest that APC subsets including DCs and macrophages not only provide "signal 1" for BCR engagement on B cells $(74,75)$, but further participate in a later stage of cell proliferation and differentiation by providing an additional "signal 2 or 3 " such as membrane-bound or soluble factors. While interruption of this pathway might represent an efficient strategy to treat autoimmune diseases, enhancing APC-B cell crosstalk, for example by targeting Ag directly to APCs, may lead to enhanced vaccine-induced $\mathrm{Ab}$ responses (Figure 3 ).

Lessons of early pioneering studies in vivo targeting DCs through coupling the antigens to a specific receptors such as DEC205, or DCIR for T cell immunity have paved a solid path toward understanding the efficiency of antigen degradation, and (cross-) presentation (76-78). Indeed, targeting antigens to DC through DCIR (79, 80), DC-SIGN (81), dectin-1 (82), ClEC9A (83), and Langerin (84) generated both humoral and cellular responses. Interestingly, in the absence of adjuvant, targeting antigens to CLEC9A on DCs results in strong antibody response, which is linked to the generation of Tfh cells (85), but no $\mathrm{CD}^{+} \mathrm{T}$ cell immunity despite of the antigen capture and cross-presentation by targeted CD $8 \alpha^{+}$DCs (83). However, an addition of adjuvant, e.g., poly I:C, skewed a robust $\mathrm{CD} 4^{+}$and $\mathrm{CD} 8^{+} \mathrm{T}$ cell response $(83,86)$. Thus, particular DC subsets, antibodies specific for surface receptors, and appropriate adjuvants, combine to define the sequential immune response by DC targeting (Table 1) (87).

The strategy of a targeted DC vaccine with an antigen to boost antibody response has met the proof of concept. In two of the studies, targeting DCs through CD11c (N418) showed robust humoral immunity resulting from germinal center formation (88, 89), though mechanistic details about antigen internalization and transfer and the factors involved in PC generation by DCs were lacking. Likely, two principles must be followed to design a better vaccine to boost $\mathrm{Ab}$ response by targeting DCs in humans; 


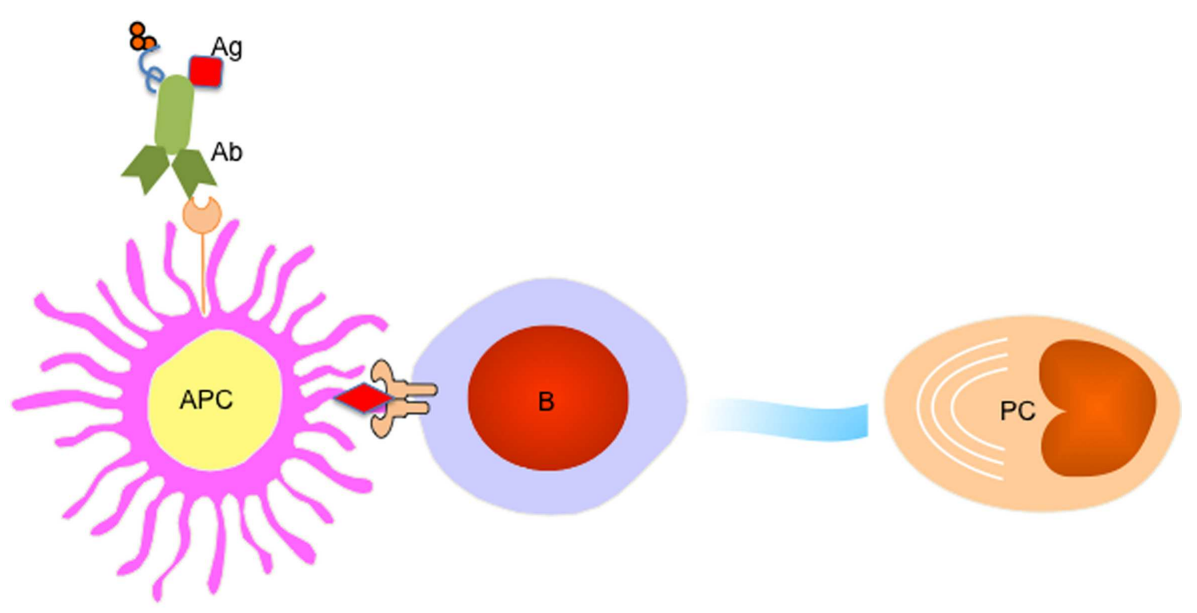

FIGURE 3 | Targeting APC subsets for a better vaccine for humoral immunity. A fusion protein of $A b$ (recognizing a particular receptor on APC subset) and Ag complex facilitates Ag uptake by targeted APC subset, which processes $\mathrm{Ag}$ to $\mathrm{B}$ cells to trigger $\mathrm{PC}$ differentiation. An adjuvant (for example IP-10) could be linked to the fusion protein to provide additional signals for PC generation and maintenance.
Table 1 | Strategy to design a APC-targeted vaccine.

\begin{tabular}{|c|c|c|}
\hline Selection of APCs & $\begin{array}{l}\text { Selection of targeting } \\
\text { receptors }\end{array}$ & $\begin{array}{l}\text { Selection of } \\
\text { adjuvant }\end{array}$ \\
\hline \multirow[t]{7}{*}{$\mathrm{DCs}$} & Fc $\gamma R \| B$ & $\mid \mathrm{P}-10$ \\
\hline & DCIR & IL-6 \\
\hline & DC-SIGN & APRIL \\
\hline & Dectin-1 & BAFF \\
\hline & CLEC9A & \\
\hline & Langerin & \\
\hline & CD11c & \\
\hline \multirow[t]{2}{*}{ Macrophages } & CD163 & \\
\hline & Fc $\gamma R \| B$ & \\
\hline
\end{tabular}

To design the appropriate targeted vaccine, three criteria need to be considered: (1) Select the appropriate DC or macrophage subsets as the targeting APCs; (2) Select appropriate receptor to target, preferentially those receptors with capacity of Ag recycling and retention, such as DCIR or FCyRIIB; (3) Select appropriate adjuvant to provide additional help for $P C$ differentiation.

(1) preferentially target interstitial dermal DCs due to their capacity to activate B cells (31); (2) preferentially deliver antigens through inhibitory receptors such as Fc $\gamma$ RIIB (50) or DCIR (52) to enable long-term retention and recycling of native antigens to the cell surfaces. The selection of adjuvant would be based on whether it needs to promote B cell differentiation (such as BAFF and APRIL), or it needs to educate Tfh cells (such as IL-6).

Our study on human macrophages in the induction of PCs (66) suggests that targeting CD163 on resident tissue macrophages would be another approach to potentially trigger preferred antibody response. IP-10 may act as a powerful adjuvant to provide the feedback loop for IL- 6 production on activated B cells. Using systems biology approach, we observed that IP-10 signature was quickly turned on after influenza vaccination in healthy individuals, and it was corresponding to the late neutralizing antibody and PC signature (90). Mice deficient for IP-10 showed reduced antibody titers against the model antigen hapten, further supporting the wide application of this macrophage-derived molecule in vaccine design (66).

Of note, targeting antigens to different subsets of APCs could lead to a differential class switching. Our preliminary data indicate that among the myeloid APCs generated from monocytes, DCs preferentially induce IgG-producing cells, whereas type 2 macrophages (M2) preferentially promote IgA-producing cells (Xu et al., unpublished). The mechanism of APC subset-mediated preferential class switching remains to be explored further. It will lead to a better understanding of vaccine design when a unique Ig subclass response is needed.

\section{CONCLUDING REMARIS}

The past decade has witnessed the important roles of DCs and macrophages in educating $\mathrm{B}$ cell activation, proliferation, and differentiation toward PCs. These APC subsets residing at distinct organs might be equipped different sentinels to initiate the prompt humoral response. For example, the subcapsular sinus macrophages, which form a thick lining beneath the capsular in the lymph node, represent the prime APCs to deliver combined signals to naïve B cells for priming. As compared to DC-targeted vaccines for $\mathrm{T}$ cell immunity that are applied for more than a decade (91), we are just beginning to design APC-targeted vaccines aiming at enhance antibody responses. As such, various studies have helped our understandings that the interplay of several distinct factors needs to be considered (1) selection of APC subsets as the target cells; (2) selection of appropriate surface receptors as the antibody target; (3) selection of adjuvant.

\section{ACKNOWLEDGMENTS}

The authors thank Katarina Kreymborg, Caroline Waltzinger, and Claire Dunn for critical reading of this manuscript. Wei $\mathrm{Xu}$ is a full-time employe of Hoffmann-La Roche Ltd. in the Switzerland. 


\section{REFERENCES}

1. Fagarasan S, Honjo TT. Independent immune response: new aspects of B cell biology. Science (2000) 290(5489):89-92. doi:10.1126/science.290.5489.89

2. Batista FD, Harwood NE. The who, how and where of antigen presentation to B cells. Nat Rev Immunol (2009) 9(1):15-27. doi:10.1038/nri2454

3. Alugupalli KR, Leong JM, Woodland RT, Muramatsu M, Honjo T, Gerstein RM. B1b lymphocytes confer T cell-independent long-lasting immunity. Immunity (2004) 21(3):379-90. doi:10.1016/j.immuni.2004.06.019

4. Obukhanych TV, Nussenzweig MC. T-independent type II immune responses generate memory B cells. J Exp Med (2006) 203(2):305-10. doi:10.1084/jem. 20052036

5. Hsu MC, Toellner KM, Vinuesa CG, Maclennan IC. B cell clones that sustain long-term plasmablast growth in T-independent extrafollicular antibody responses. Proc Natl Acad Sci U S A (2006) 103(15):5905-10. doi:10.1073/pnas. 0601502103

6. Kapsenberg ML. Dendritic-cell control of pathogen-driven T-cell polarization. Nat Rev Immunol (2003) 3(12):984-93. doi:10.1038/nri1246

7. Schuler G, Steinman RM. Murine epidermal Langerhans cells mature into poten immunostimulatory dendritic cells in vitro. J Exp Med (1985) 161(3):526-46. doi:10.1084/jem.161.3.526

8. Caux C, Dezutter-Dambuyant C, Schmitt D, Banchereau J. GM-CSF and TNFalpha cooperate in the generation of dendritic Langerhans cells. Nature (1992) 360(6401):258-61. doi:10.1038/360258a0

9. Dubois B, Bridon JM, Fayette J, Barthelemy C, Banchereau J, Caux C, et al. Dendritic cells directly modulate B cell growth and differentiation. J Leukoc Biol (1999) 66(2):224-30.

10. Dubois B, Vanbervliet B, Fayette J, Massacrier C, Van Kooten C, Briere F, et al. Dendritic cells enhance growth and differentiation of CD40-activated B lymphocytes. J Exp Med (1997) 185(5):941-51. doi:10.1084/jem.185.5.941

11. Fayette J, Dubois B, Vandenabeele S, Bridon JM, Vanbervliet B, Durand I, et al. Human dendritic cells skew isotype switching of CD40-activated naive B cells towards IgA1 and IgA2. J Exp Med (1997) 185(11):1909-18. doi:10.1084/jem. 185.11.1909

12. Wykes M, Pombo A, Jenkins C, MacPherson GG. Dendritic cells interact directly with naive $\mathrm{B}$ lymphocytes to transfer antigen and initiate class switching in a primary T-dependent response. J Immunol (1998) 161(3):1313-9.

13. Litinskiy MB, Nardelli B, Hilbert DM, He B, Schaffer A, Casali P, et al. DCs induce CD40-independent immunoglobulin class switching through BLyS and APRIL. Nat Immunol (2002) 3(9):822-9. doi:10.1038/ni829

14. Yan M, Marsters SA, Grewal IS, Wang H, Ashkenazi A, Dixit VM. Identification of a receptor for BLyS demonstrates a crucial role in humoral immunity. Nat Immunol (2000) 1(1):37-41. doi:10.1038/76889

15. Thompson JS, Schneider P, Kalled SL, Wang L, Lefevre EA, Cachero TG, et al. BAFF binds to the tumor necrosis factor receptor-like molecule B cell maturation antigen and is important for maintaining the peripheral B cell population. J Exp Med (2000) 192(1):129-35. doi:10.1084/jem.192.1.129

16. Gross JA, Johnston J, Mudri S, Enselman R, Dillon SR, Madden K, et al. TACI and BCMA are receptors for a TNF homologue implicated in B-cell autoimmune disease. Nature (2000) 404(6781):995-9. doi:10.1038/35010115

17. Thompson JS, Bixler SA, Qian F, Vora K, Scott ML, Cachero TG, et al. BAFF-R, a newly identified TNF receptor that specifically interacts with BAFF. Science (2001) 293(5537):2108-11. doi:10.1126/science.1061965

18. Gross JA, Dillon SR, Mudri S, Johnston J, Littau A, Roque R, et al. TACI-Ig neutralizes molecules critical for B cell development and autoimmune disease. impaired B cell maturation in mice lacking BLyS. Immunity (2001) 15(2):289-302. doi:10.1016/S1074-7613(01)00183-2

19. Rennert P, Schneider P, Cachero TG, Thompson J, Trabach L, Hertig S, et al. A soluble form of B cell maturation antigen, a receptor for the tumor necrosis factor family member APRIL, inhibits tumor cell growth. J Exp Med (2000) 192(11):1677-84. doi:10.1084/jem.192.11.1677

20. Hahne M, Kataoka T, Schroter M, Hofmann K, Irmler M, Bodmer JL, et al. APRIL, a new ligand of the tumor necrosis factor family, stimulates tumor cell growth. J Exp Med (1998) 188(6):1185-90. doi:10.1084/jem.188.6.1185

21. Do RK, Hatada E, Lee H, Tourigny MR, Hilbert D, Chen-Kiang S. Attenuation of apoptosis underlies B lymphocyte stimulator enhancement of humoral immune response. J Exp Med (2000) 192(7):953-64. doi:10.1084/jem.192.7.953

22. Park SR, Kim PH, Lee KS, Lee SH, Seo GY, Yoo YC, et al. APRIL stimulates NF-kappaB-mediated HoxC4 induction for AID expression in mouse B cells. Cytokine (2013) 61(2):608-13. doi:10.1016/j.cyto.2012.10.018
23. Schiemann B, Gommerman JL, Vora K, Cachero TG, Shulga-Morskaya S, Dobles $\mathrm{M}$, et al. An essential role for BAFF in the normal development of B cells through a BCMA-independent pathway. Science (2001) 293(5537):2111-4. doi:10.1126/science.1061964

24. Castigli E, Scott S, Dedeoglu F, Bryce P, Jabara H, Bhan AK, et al. Impaired IgA class switching in APRIL-deficient mice. Proc Natl Acad Sci U S A (2004) 101(11):3903-8. doi:10.1073/pnas.0307348101

25. Shortman K, Liu YJ. Mouse and human dendritic cell subtypes. Nat Rev Immunol (2002) 2(3):151-61. doi:10.1038/nri746

26. Dzionek A, Fuchs A, Schmidt P, Cremer S, Zysk M, Miltenyi S, et al. BDCA-2, BDCA-3, and BDCA-4: three markers for distinct subsets of dendritic cells in human peripheral blood. J Immunol (2000) 165(11):6037-46.

27. Dzionek A, Sohma Y, Nagafune J, Cella M, Colonna M, Facchetti F, et al. BDCA2, a novel plasmacytoid dendritic cell-specific type II C-type lectin, mediates antigen capture and is a potent inhibitor of interferon alpha/beta induction. J Exp Med (2001) 194(12):1823-34. doi:10.1084/jem.194.12.1823

28. MacDonald KP, Munster DJ, Clark GJ, Dzionek A, Schmitz J, Hart DN. Characterization of human blood dendritic cell subsets. Blood (2002) 100(13):4512-20. doi:10.1182/blood-2001-11-0097

29. Nestle FO, Di Meglio P, Qin JZ, Nickoloff BJ. Skin immune sentinels in health and disease. Nat Rev Immunol (2009) 9(10):679-91. doi:10.1038/nri2622

30. Joffre OP, Segura E, Savina A, Amigorena S. Cross-presentation by dendritic cells. Nat Rev Immunol (2012) 12(8):557-69. doi:10.1038/nri3254

31. Klechevsky E, Morita R, Liu M, Cao Y, Coquery S, Thompson-Snipes L, et al. Functional specializations of human epidermal Langerhans cells and CD14+ dermal dendritic cells. Immunity (2008) 29(3):497-510. doi:10.1016/j.immuni. 2008.07.013

32. Crotty S. Follicular helper CD4 T cells (TFH). Annu Rev Immunol (2011) 29:621-63. doi:10.1146/annurev-immunol-031210-101400

33. Schmitt N, Bustamante J, Bourdery L, Bentebibel SE, Boisson-Dupuis S, Hamlin F, et al. IL-12 receptor betal deficiency alters in vivo $\mathrm{T}$ follicular helper cell response in humans. Blood (2013) 121(17):3375-85. doi:10.1182/blood-201208-448902

34. Schmitt N, Morita R, Bourdery L, Bentebibel SE, Zurawski SM, Banchereau $\mathrm{J}$, et al. Human dendritic cells induce the differentiation of interleukin-21producing T follicular helper-like cells through interleukin-12. Immunity (2009) 31(1):158-69. doi:10.1016/j.immuni.2009.04.016

35. Jego G, Palucka AK, Blanck JP, Chalouni C, Pascual V, Banchereau J. Plasmacytoid dendritic cells induce plasma cell differentiation through type I interferon and interleukin 6. Immunity (2003) 19(2):225-34. doi:10.1016/S1074-7613(03) 00208-5

36. Poeck H, Wagner M, Battiany J, Rothenfusser S, Wellisch D, Hornung V, et al. Plasmacytoid dendritic cells, antigen, and CpG-C license human B cells for plasma cell differentiation and immunoglobulin production in the absence of T-cell help. Blood (2004) 103(8):3058-64. doi:10.1182/blood-2003-08-2972

37. Shaw J, Wang YH, Ito T, Arima K, Liu YJ. Plasmacytoid dendritic cells regulate B-cell growth and differentiation via CD70. Blood (2010) 115(15):3051-7. doi:10.1182/blood-2009-08-239145

38. Tangye SG, Bryant VL, Cuss AK, Good KLBAFF. APRIL and human B cell disorders. Semin Immunol (2006) 18(5):305-17. doi:10.1016/j.smim.2006.04.004

39. Cucak H, Yrlid U, Reizis B, Kalinke U, Johansson-Lindbom B. Type I interferon signaling in dendritic cells stimulates the development of lymph-node-resident T follicular helper cells. Immunity (2009) 31(3):491-501. doi:10.1016/j.immuni. 2009.07.005

40. Blanco P, Palucka AK, Gill M, Pascual V, Banchereau J. Induction of dendritic cell differentiation by IFN-alpha in systemic lupus erythematosus. Science (2001) 294(5546):1540-3. doi:10.1126/science.1064890

41. Bennett L, Palucka AK, Arce E, Cantrell V, Borvak J, Banchereau J, et al. Interferon and granulopoiesis signatures in systemic lupus erythematosus blood. J Exp Med (2003) 197(6):711-23. doi:10.1084/jem.20021553

42. Santiago-Raber ML, Baccala R, Haraldsson KM, Choubey D, Stewart TA, Kono $\mathrm{DH}$, et al. Type-I interferon receptor deficiency reduces lupus-like disease in NZB mice. J Exp Med (2003) 197(6):777-88. doi:10.1084/jem.20021996

43. Ding C, Cai Y, Marroquin J, Ildstad ST, Yan J. Plasmacytoid dendritic cells regulate autoreactive B cell activation via soluble factors and in a cell-to-cell contact manner. J Immunol (2009) 183(11):7140-9. doi:10.4049/jimmunol.0901175

44. Delamarre L, Pack M, Chang H, Mellman I, Trombetta ES. Differential lysosomal proteolysis in antigen-presenting cells determines antigen fate. Science (2005) 307(5715):1630-4. doi:10.1126/science.1108003 
45. Garcia De Vinuesa C, Gulbranson-Judge A, Khan M, O'Leary P, Cascalho M, Wabl M, et al. Dendritic cells associated with plasmablast survival. Eur J Immunol (1999) 29(11):3712-21. doi:10.1002/(SICI)1521-4141(199911)29: $11<3712:: A I D-I M M U 3712>3.0 . C O ; 2-P$

46. Balazs M, Martin F, Zhou T, Kearney J. Blood dendritic cells interact with splenic marginal zone B cells to initiate T-independent immune responses. Immunity (2002) 17(3):341-52. doi:10.1016/S1074-7613(02)00389-8

47. Macpherson AJ, Uhr T. Induction of protective IgA by intestinal dendritic cells carrying commensal bacteria. Science (2004) 303(5664):1662-5. doi:10.1126/ science. 1091334

48. Niess JH, Brand S, Gu X, Landsman L, Jung S, McCormick BA, et al. CX3CR1mediated dendritic cell access to the intestinal lumen and bacterial clearance. Science (2005) 307(5707):254-8. doi:10.1126/science.1102901

49. Qi H, Egen JG, Huang AY, Germain RN. Extrafollicular activation of lymph node B cells by antigen-bearing dendritic cells. Science (2006) 312(5780):1672-6. doi:10.1126/science. 1125703

50. Bergtold A, Desai DD, Gavhane A, Clynes R. Cell surface recycling of internalized antigen permits dendritic cell priming of B cells. Immunity (2005) 23(5):503-14. doi:10.1016/j.immuni.2005.09.013

51. Heesters BA, Chatterjee P, Kim YA, Gonzalez SF, Kuligowski MP, Kirchhausen $\mathrm{T}$, et al. Endocytosis and recycling of immune complexes by follicular dendritic cells enhances B cell antigen binding and activation. Immunity (2013) 38(6):1164-75. doi:10.1016/j.immuni.2013.02.023

52. Chappell CP, Draves KE, Giltiay NV, Clark EA. Extrafollicular B cell activation by marginal zone dendritic cells drives $\mathrm{T}$ cell-dependent antibody responses. J Exp Med (2012) 209(10):1825-40. doi:10.1084/jem.20120774

53. Le Roux D, Le Bon A, Dumas A, Taleb K, Sachse M, Sikora R, et al. Antigen stored in dendritic cells after macropinocytosis is released unprocessed from late endosomes to target B cells. Blood (2012) 119(1):95-105. doi:10.1182/blood-201102-336123

54. Farr AG, Cho Y, De Bruyn PP. The structure of the sinus wall of the lymph node relative to its endocytic properties and transmural cell passage. Am J Anat (1980) 157(3):265-84. doi:10.1002/aja.1001570304

55. Fossum S. The architecture of rat lymph nodes. IV. Distribution of ferritin and colloidal carbon in the draining lymph nodes after foot-pad injection. Scand J Immunol (1980) 12(5):433-41. doi:10.1111/j.1365-3083.1980.tb00087.x

56. Szakal AK, Holmes KL, Tew JG. Transport of immune complexes from the subcapsular sinus to lymph node follicles on the surface of nonphagocytic cells, including cells with dendritic morphology. J Immunol (1983) 131(4):1714-27.

57. Unanue ER, Cerottini JC, Bedford M. Persistence of antigen on the surface of macrophages. Nature (1969) 222(5199):1193-5. doi:10.1038/2221193a0

58. Phan TG, Grigorova I, Okada T, Cyster JG. Subcapsular encounter and complement-dependent transport of immune complexes by lymph node B cells. Nat Immunol (2007) 8(9):992-1000. doi:10.1038/nil494

59. Junt T, Moseman EA, Iannacone M, Massberg S, Lang PA, Boes M, et al. Subcapsular sinus macrophages in lymph nodes clear lymph-borne viruses and present them to antiviral B cells. Nature (2007) 450(7166):110-4. doi:10.1038/ nature 06287

60. Carrasco YR, Batista FD. B cells acquire particulate antigen in a macrophage-rich area at the boundary between the follicle and the subcapsular sinus of the lymph node. Immunity (2007) 27(1):160-71. doi:10.1016/j.immuni.2007.06.007

61. Phan TG, Green JA, Gray EE, Xu Y, Cyster JG. Immune complex relay by subcapsular sinus macrophages and noncognate B cells drives antibody affinity maturation. Nat Immunol (2009) 10(7):786-93. doi:10.1038/ni.1745

62. Martinez-Pomares L, Kosco-Vilbois M, Darley E, Tree P, Herren S, Bonnefoy JY, et al. Fc chimeric protein containing the cysteine-rich domain of the murine mannose receptor binds to macrophages from splenic marginal zone and lymph node subcapsular sinus and to germinal centers. J Exp Med (1996) 184(5):1927-37. doi:10.1084/jem.184.5.1927

63. Karlsson MC, Guinamard R, Bolland S, Sankala M, Steinman RM, Ravetch JV. Macrophages control the retention and trafficking of B lymphocytes in the splenic marginal zone. J Exp Med (2003) 198(2):333-40. doi:10.1084/jem. 20030684

64. Zhang L, Yankelevitz DF, Henschke CI, Jirapatnakul AC, Reeves AP, Carter D. Zone of transition: a potential source of error in tumor volume estimation. Radiology (2010) 256(2):633-9. doi:10.1148/radiol.10090924

65. Koppel EA, Wieland CW, van den Berg VC, Litjens M, Florquin S, van Kooyk Y, et al. Specific ICAM-3 grabbing nonintegrin-related 1 (SIGNR1) expressed by marginal zone macrophages is essential for defense against pulmonary Streptococcus pneumoniae infection. Eur J Immunol (2005) 35(10):2962-9. doi:10.1002/eji.200526216

66. Xu W, Joo H, Clayton S, Dullaers M, Herve MC, Blankenship D, et al. Macrophages induce differentiation of plasma cells through CXCL10/IP-10. J Exp Med (2012) 209(10):1813-23. doi:10.1084/jem.20112142

67. Carrasco YR, Batista FD. B-cell activation by membrane-bound antigens is facilitated by the interaction of VLA-4 with VCAM-1. EMBO J (2006) 25(4):889-99. doi:10.1038/sj.emboj.7600944

68. Nardelli B, Belvedere O, Roschke V, Moore PA, Olsen HS, Migone TS, et al. Synthesis and release of B-lymphocyte stimulator from myeloid cells. Blood (2001) 97(1):198-204. doi:10.1182/blood.V97.1.198

69. Craxton A, Magaletti D, Ryan EJ, Clark EA. Macrophage- and dendritic cell dependent regulation of human B-cell proliferation requires the TNF family ligand BAFF. Blood (2003) 101(11):4464-71. doi:10.1182/blood-2002-10-3123

70. Joo H, Coquery C, Xue Y, Gayet I, Dillon SR, Punaro M, et al. Serum from patients with SLE instructs monocytes to promote IgG and IgA plasmablast differentiation. J Exp Med (2012) 209(7):1335-48. doi:10.1084/jem.20111644

71. Mohr E, Serre K, Manz RA, Cunningham AF, Khan M, Hardie DL, et al. Dendritic cells and monocyte/macrophages that create the IL-6/APRIL-rich lymph node microenvironments where plasmablasts mature. J Immunol (2009) 182(4):2113-23. doi:10.4049/jimmunol.0802771

72. Matthes T, Dunand-Sauthier I, Santiago-Raber ML, Krause KH, Donze O, Passweg J, et al. Production of the plasma-cell survival factor a proliferation-inducing ligand (APRIL) peaks in myeloid precursor cells from human bone marrow. Blood (2011) 118(7):1838-44. doi:10.1182/blood-2011-01-332940

73. Chu VT, Frohlich A, Steinhauser G, Scheel T, Roch T, Fillatreau S, et al. Eosinophils are required for the maintenance of plasma cells in the bone marrow. Nat Immunol (2011) 12(2):151-9. doi:10.1038/ni.1981

74. Harwood NE, Batista FD. Early events in B cell activation. Annu Rev Immunol (2010) 28:185-210. doi:10.1146/annurev-immunol-030409-101216

75. Pierce SK, Liu W. The tipping points in the initiation of B cell signalling: how small changes make big differences. Nat Rev Immunol (2010) 10(11):767-77. doi:10.1038/nri2853

76. Soares H, Waechter H, Glaichenhaus N, Mougneau E, Yagita H, Mizenina O, et al. A subset of dendritic cells induces CD4+ T cells to produce IFN-gamma by an IL-12-independent but CD70-dependent mechanism in vivo. J Exp Med (2007) 204(5):1095-106. doi:10.1084/jem.20070176

77. Hawiger D, Inaba K, Dorsett Y, Guo M, Mahnke K, Rivera M, et al. Dendritic cells induce peripheral $\mathrm{T}$ cell unresponsiveness under steady state conditions in vivo. J Exp Med (2001) 194(6):769-79. doi:10.1084/jem.194.6.769

78. Bonifaz L, Bonnyay D, Mahnke K, Rivera M, Nussenzweig MC, Steinman RM. Efficient targeting of protein antigen to the dendritic cell receptor DEC-205 in the steady state leads to antigen presentation on major histocompatibility complex class I products and peripheral CD8+ T cell tolerance. J Exp Med (2002) 196(12):1627-38. doi:10.1084/jem.20021598

79. Klechevsky E, Flamar AL, Cao Y, Blanck JP, Liu M, O’Bar A, et al. Cross-priming CD8+ T cells by targeting antigens to human dendritic cells through DCIR. Blood (2010) 116(10):1685-97. doi:10.1182/blood-2010-01-264960

80. Meyer-Wentrup F, Cambi A, Joosten B, Looman MW, de Vries IJ, Figdor CG, et al. DCIR is endocytosed into human dendritic cells and inhibits TLR8mediated cytokine production. J Leukoc Biol (2009) 85(3):518-25. doi:10.1189/ jlb.0608352

81. Dakappagari N, Maruyama T, Renshaw M, Tacken P, Figdor C, Torensma R, et al. Internalizing antibodies to the C-type lectins, L-SIGN and DC-SIGN, inhibit viral glycoprotein binding and deliver antigen to human dendritic cells for the induction of T cell responses. J Immunol (2006) 176(1):426-40.

82. Ni L, Gayet I, Zurawski S, Duluc D, Flamar AL, Li XH, et al. Concomitant activation and antigen uptake via human dectin-1 results in potent antigen-specific CD8+ T cell responses. J Immunol (2010) 185(6):3504-13. doi:10.4049/jimmunol.1000999

83. Sancho D, Mourao-Sa D, Joffre OP, Schulz O, Rogers NC, Pennington DJ, et al. Tumor therapy in mice via antigen targeting to a novel, DC-restricted C-type lectin. J Clin Invest (2008) 118(6):2098-110. doi:10.1172/JCI34584

84. Flacher V, Sparber F, Tripp CH, Romani N, Stoitzner P. Targeting of epidermal Langerhans cells with antigenic proteins: attempts to harness their properties for immunotherapy. Cancer Immunol Immunother (2009) 58(7):1137-47. doi:10.1007/s00262-008-0563-9 
85. Caminschi I, Vremec D, Ahmet F, Lahoud MH, Villadangos JA, Murphy KM, et al. Antibody responses initiated by Clec9A-bearing dendritic cells in normal and Batf3(-/-) mice. Mol Immunol (2012) 50(1-2):9-17. doi:10.1016/j.molimm. 2011.11.008

86. Joffre OP, Sancho D, Zelenay S, Keller AM, Reis e Sousa C. Efficient and versatile manipulation of the peripheral CD4+ T-cell compartment by antigen targeting to DNGR-1/CLEC9A. Eur J Immunol (2010) 40(5):1255-65. doi:10.1002/eji.201040419

87. Palucka K, Banchereau J. Dendritic-cell-based therapeutic cancer vaccines. Immunity (2013) 39(1):38-48. doi:10.1016/j.immuni.2013.07.004

88. Wang H, Griffiths MN, Burton DR, Ghazal P. Rapid antibody responses by lowdose, single-step, dendritic cell-targeted immunization. Proc Natl Acad Sci U S A (2000) 97(2):847-52. doi:10.1073/pnas.97.2.847

89. White AL, Tutt AL, James S, Wilkinson KA, Castro FV, Dixon SV, et al. Ligation of CD11c during vaccination promotes germinal centre induction and robust humoral responses without adjuvant. Immunology (2010) 131(1):141-51. doi: 10.1111/j.1365-2567.2010.03285.x

90. Obermoser G, Presnell S, Domico K, Xu H, Wang Y, Anguiano E, et al. Systems scale interactive exploration reveals quantitative and qualitative differences in response to influenza and pneumococcal vaccines. Immunity (2013) 38(4):831-44. doi:10.1016/j.immuni.2012.12.008
91. Hsu FJ, Benike C, Fagnoni F, Liles TM, Czerwinski D, Taidi B, et al. Vaccination of patients with B-cell lymphoma using autologous antigen-pulsed dendritic cells. Nat Med (1996) 2(1):52-8. doi:10.1038/nm0196-52

Conflict of Interest Statement: The authors declare that the research was conducted in the absence of any commercial or financial relationships that could be construed as a potential conflict of interest.

Received: 24 October 2013; accepted: 20 December 2013; published online: 06 January 2014.

Citation: $X u W$ and Banchereau J (2014) The antigen presenting cells instruct plasma cell differentiation. Front. Immunol. 4:504. doi: 10.3389/fimmu.2013.00504

This article was submitted to B Cell Biology, a section of the journal Frontiers in Immunology.

Copyright $\odot 2014$ Xu and Banchereau. This is an open-access article distributed under the terms of the Creative Commons Attribution License (CC BY). The use, distribution or reproduction in other forums is permitted, provided the original author $(s)$ or licensor are credited and that the original publication in this journal is cited, in accordance with accepted academic practice. No use, distribution or reproduction is permitted which does not comply with these terms. 